\title{
Updated Dosing Instructions for Immune Globulin (Human) GamaSTAN S/D for Hepatitis A Virus Prophylaxis
}

\author{
Noele P. Nelson, $\mathrm{MD}^{1}$
}

GamaSTAN S/D (Grifols Therapeutics, Inc., Research Triangle Park, North Carolina) is a sterile, preservative-free solution of immune globulin (IG) for intramuscular administration and is used for prophylaxis against disease caused by infection with hepatitis A, measles, varicella, and rubella viruses (1). GamaSTAN S/D is the only IG product approved by the Food and Drug Administration for hepatitis A virus (HAV) prophylaxis. In July 2017, GamaSTAN S/D prescribing information was updated with changes to the dosing instructions for hepatitis A preexposure and postexposure prophylaxis indications. These changes were made because of concerns about decreased HAV immunoglobulin G antibody (anti-HAV IgG) potency, likely resulting from decreasing prevalence of previous HAV infection among plasma donors, leading to declining anti-HAV antibody levels in donor plasma (2). No changes in dosing instructions were made for measles, varicella, or rubella preexposure or postexposure prophylaxis.

Following are the updated recommended doses of GamaSTAN S/D for hepatitis A preexposure and postexposure prophylaxis (2).

\section{Preexposure Prophylaxis in Persons Who Plan to Travel in Areas with High or Intermediate Hepatitis A Endemicity}

The recommended dosages of GamaSTAN S/D, which vary according to planned duration of travel are as follows (Table):

- Up to 1 month: $0.1 \mathrm{~mL} / \mathrm{kg}$

- Up to 2 months: $0.2 \mathrm{~mL} / \mathrm{kg}$

- 2 months or longer: repeat dose of $0.2 \mathrm{~mL} / \mathrm{kg}$ every 2 months.

\section{Postexposure Prophylaxis of Household and Institutional Hepatitis A Case Contacts}

The recommended dosage of GamaSTAN S/D is $0.1 \mathrm{~mL} / \mathrm{kg}$ (Table). There is no maximum dosage of GamaSTAN S/D for hepatitis A prophylaxis (1).

The effect of IG preparations on the response to certain live-virus vaccines is unknown, but antibodies in GamaSTAN S/D might interfere with live-virus vaccines such as measles, mumps, and rubella (MMR) vaccine and varicella vaccine $(1,3)$. The recommendations for the timing of administration of GamaSTAN S/D with live-virus vaccines has not changed $(1,3)$. The Advisory Committee on Immunization Practices
TABLE. Indications and updated dosage recommendations for GamaSTAN S/D human immune globulin for preexposure and postexposure prophylaxis against hepatitis $A$ infection
Indication

Preexposure prophylaxis

Up to 1 month of travel

Up to 2 months of travel

2 months of travel or longer

Postexposure prophylaxis
Updated dosage recommendation

$0.1 \mathrm{~mL} / \mathrm{kg}$

$0.2 \mathrm{~mL} / \mathrm{kg}$

$0.2 \mathrm{~mL} / \mathrm{kg}$ (repeat every 2 months) $0.1 \mathrm{~mL} / \mathrm{kg}$
(ACIP) recommends that MMR and varicella vaccines should be administered at least 2 weeks before or at least 3 months after the administration of IG preparations (1). If an IG preparation must be administered less than 2 weeks after the administration of MMR or varicella vaccine, the patient should be revaccinated no sooner than 3 months after receipt of the IG preparation.

The absolute lower limit of anti-HAV IgG required to prevent HAV infection has not been defined; however, $10 \mathrm{mIU} / \mathrm{mL}$ is considered to be the minimum protective level for HAV prophylaxis $(1,4)$. The minimum anti-HAV IgG potency specified by the European Pharmacopoeia for intramuscular IG preparations indicated for HAV prophylaxis is $>100 \mathrm{IU} / \mathrm{mL}$ (5). A recent study showed that only two of nine tested lots of commercially available IG preparations manufactured in the United States, Europe, and Asia had anti-HAV IgG potency of $100 \mathrm{IU} / \mathrm{mL}$ ( (). In addition, anti-HAV IgG decay models indicate that only five of nine lots of IG dosed at $0.02 \mathrm{~mL} / \mathrm{kg}$ achieved postabsorption plasma anti-HAV IgG levels above the minimum protective level of $10 \mathrm{mIU} / \mathrm{mL}(\sigma)$. The decay model also showed that none of the tested IG lots maintained the proposed minimal protective anti-HAV IgG level of $10 \mathrm{mIU} / \mathrm{mL}$ for 3 months (б).

Indications for the use of IG are based on ACIP recommendations published in 2007 for prevention of hepatitis A infection after exposure to HAV and in international travelers (7).

\section{Preexposure Prophylaxis for International Travel}

Hepatitis A vaccine at the age-appropriate dose is preferred to IG. For travel that will begin in $\leq 2$ weeks to countries with high or intermediate hepatitis A endemicity, older adults, immunocompromised persons, and persons with chronic liver disease or other chronic medical conditions may receive IG simultaneously with hepatitis A vaccine at a separate anatomic injection site. Travelers who elect not to receive hepatitis A vaccine, who are aged $<12$ months, or who are allergic to a component of hepatitis A vaccine should receive a single dose of IG before travel ( 7$)$. 


\section{Postexposure Prophylaxis}

IG should be used for children aged $<12$ months, immunocompromised persons, persons who have chronic liver disease, and persons for whom vaccine is contraindicated. IG is also preferred over hepatitis A vaccine for persons aged $>40$ years; however, vaccine may be used if IG cannot be obtained (7).

\section{Conflict of Interest}

No conflicts of interest were reported.

\footnotetext{
${ }^{1}$ Division of Viral Hepatitis, National Center for HIV/AIDS, Viral Hepatitis, STD, and TB Prevention, CDC.
}

Corresponding author: Noele P. Nelson, nnelson@cdc.gov, 404-718-8576.

\section{References}

1. GamaSTAN S/D. Package insert. Research Triangle Park, NC: Grifols; 2005. https://www.fda.gov/downloads/BiologicsBloodVaccines/ BloodBloodProducts/ApprovedProducts/LicensedProductsBLAs/ FractionatedPlasmaProducts/UCM371376.pdf
2. Important change in prescribing information immune globulin (human): GamaSTAN S/D https://www.hypermunes.com/ documents/24720443/24803488/Healthcare+Provider+Letter+Gam aSTAN+SD+Revised+Dosage+July+7+2017_with+LIT+CODE.pdf/ b831e 517-9d0b-472c-b5b5-719f5bb5e47c

3. Kroger AT, Duchin J, Vázquez M. General best practice guidelines for immunization. Best practices guidance of the Advisory Committee on Immunization Practices (ACIP). https://www.cdc.gov/vaccines/hcp/aciprecs/general-recs/index.html

4. Fiore AE, Wasley A, Bell BP. Prevention of hepatitis A through active or passive immunization: recommendations of the Advisory Committee on Immunization Practices (ACIP). MMWR Recomm Rep 2006;55(No. RR-7).

5. Council of Europe. European pharmacopoeia. 8th ed. Strasbourg, France: Council of Europe; 2015.

6. Tejada-Strop A, Costafreda MI, Dimitrova Z, Kaplan GG, Teo CG. Evaluation of potencies of immune globulin products against hepatitis A. JAMA Intern Med 2017;177:430-2. https://doi.org/10.1001/ jamainternmed.2016.9057

7. CDC. Update: prevention of hepatitis A after exposure to hepatitis A virus and in international travelers. Updated recommendations of the Advisory Committee on Immunization Practices (ACIP). MMWR Morb Mortal Wkly Rep 2007;56:1080-4. 